\title{
KESETARAAN HAK DALAM PENDIDIKAN (STUDI PADA SEJARAH PERJUANGAN RAHMAH ELYUNUSIYAH DALAM MEMPERJUANGKAN HAK-HAK WANITA DALAM PENDIDIKAN)
}

\author{
Hairuddin Cikka
}

\begin{abstract}
For most Indonesians, a priori attitudes towards women in school are still the main domain of daily life. Just look at how the term kitchen-well-mattress is so popular among the people. This expression wants to emphasize that as powerful and as smart as any woman, in the end the "nature" and "destiny" of women will return to domestic life that only deal with matters of cooking, washing and sex. This assumption has been going on for hundreds of years and is not new. Even in matrilineal societies, such as West Sumatra, the birthplace and struggle of Rahmah, the assumption that women are not suitable to study is often discussed.

Rahmah is one of the few women who rejects this stereotype. For him, women have the same learning and teaching rights as men. In fact, compared to men, women are also able to have intelligence that is no less great. The problem lies in access to education. At that time, long before Indonesia's independence, the education system in the archipelago was still far from what was expected and women did not have access to the same education as men.

For her, even though a woman only plays the role of a housewife, she still has social responsibility for the welfare of the community, religion, and motherland. That responsibility can be given through education, both in the family (domestic) and in schools (public). Perhaps, if Rahmah were still alive, he would agree with the current idea that building a society without involving women is like a bird flying with one wing. Educating a woman means educating all men. Because, as many people believe, education can make a major contribution to efforts to modernize a society. And it seems Rahmah has worked for it.
\end{abstract}

\section{Keywords: Equality of Rights in Education}

\section{PENDAHULUAN}

Rahmah El-Yunusiah, merupakan salah satu tokoh pendidik dari tanah minang dan beliau tidak tercatat sebagai salah satu nama pahlawan nasional. Namanya juga masih snagat asing didengar dan belum banyak dikenal di dunia pendidikan. Tak semasyhur nama besar pahlawan wanita seperti Cut Nyak Dien, Dewi Sartika, ataupun Raden Ajeng Kartini. Walaupun begitu, perjuangannya dalam pendidikan tidak dapat diragukan lagi. Rahmah El-Yunusiah yang lahir 
pada tanggal 1 Rajab 1318 Hijriyah atau 20 Desember 1900 di jalan Lubuk Mata Kucing, Kanagarian, Bukit Surungan, Padang Panjang, tanah Minangkabau. Anak bungsu dari lima bersaudara, yaitu Zainuddin Labay (1890-1924 M), Mariah (1893-1972 M), Muhammad Rasyad (1895-1956 M), dan Rihanah (1898-1968 M).

Ayahnya bernama Syaikh Muhammad Yunus (1846-1906 M) yang dikenal sebagai sebagai salahsatu ulama besar dan seorang qadhil hakim yang ahli ilmu falak dan hisab di Pandai Sikat. Riwayat pendidikannya, pernah belajar selama 4 tahun di Mekkah. Sedangkan ibunya Rafi'ah dari keturunan suku Sikumbang yang berasal dari Langkat, Bukittinggi Kabupaten Agam. Ibunya juga masih berdarah keturunan ulama, empat tingkat diatasnya masih ada hubungan dengan mamak Haji Miskin, seorang pembaharu gerakan Paderi. Ibunya hijrah ke bukit Surungan Padang Panjang pada abad XVIII M yang lalu. Dan menikah di usia yang belia, yaitu 16 tahun sedangkan Syaikh Muhammad Yunus telah berumur 42 tahun. $^{2}$

Syeikh Imaduddin merupakan kakek dari Rahmah El-Yunusiah yang dikenal sebagai salah satu ulama yang pakar dalam ilmu falak dan merupakan tokoh tarekat Naqsyabandiyah Khalidiyah di Tanah Minang. Beliau adalah ulama yang masih bertalian darah dengan keturunan pembaharu Islam yang merupakan tokoh Paderi, Tuanku Nan Pulang di Rao dari sini, berarti Rahmah hidup dalam lingkunngan kreluarga ulama sehingga memudahkannya mendapatkan pendidikan.

Kemudian dari latar keluarganya yang patuh dalam beragama, Rahmah telah mendapat didikan dari bapaknya, namun masa belajar itu hanya berlangsung singkat karena ayahnya meninggal pada saat ia masih kanak-kanak. Rahmah kecil diasuh dan dibesarkan oleh sang ibu dan peranan bapaknya sebagai orang tua digantikan oleh dua orang saudaranya yakni Zainuddin Labay El-Yunusiy dan M. Rasyad yang masing-masing telah berumah tangga. Kakaknya Zainuddin adalah

${ }^{1}$ Rohmatun Lukluk Isnaini, Ulama Perempuan dan Dedikasinya Dalam Pendidikan Islam (Telaah Pemikiran Rahmah El-Yunusiyah), Jurnal Pendidikan Agama Islam Volume 4 Nomor 1 Mei 2016 ISSN (p) 2089-1946 \& ISSN(e) 2527-4511 223 -3 ${ }^{2}$ Ibid., 
salah seorang tokoh pembaharu di Sumatra Barat. Zainuddin Labay merupakan salah satu tokoh pendidik yang mendirikan Diniyah School di Sumatra. Kakaknya itu menguasai beberapa bahasa asing seperti Inggris, Arab, dan Belanda sehingga banyak membantu Rahmah mengakses sejumlah literatur asing. Rahmah sangat menyegani dan mengagumi kakaknya ini. Baginya Zainudin adalah seorang pemberi inspirasi, pendukung cita-cita, dan seorang guru baginya. ${ }^{3}$

Hijriyah atau tanggal 26 Februari 1969 pada pukul 19.30 di rumahnya sendiri di Padang Panjang, Rahmah El-Yunusiyah wafat pada usia 68 tahun 2 bulan. Jenazahnya dikuburkan di perkuburan keluarga disamping rumahnya yang juga disamping perguruan yang ia dirikan dipinggir jalan Lubuk Mata Kucing. Meskipun jasadnya telah mati terkubur namun jasa peninggalan perjuangannya bagi perempuan masih bisa terus dikenang. Pengorbanan dalam hidupnya tidaklah sia-sia, perjuangan dan dedikasinya dalam bidang pendidikan banyak memberi manfaat besar bagi agama, kehidupan masyarakat dan negara khususnya perempuan. Inilah nama besar Rahmah El-Yunusiyah sebagai ulama perempuan yang memperjuangkan pendidikan perempuan Indonesia. ${ }^{4}$

Rahmah memandang mempunyai peranan penting dalam kehidupan. Perempuan adalah pendidik pertama dan utam bagi anak-anak yang akan menjadi generasi penerus bangsa. Atas dasar itu, untuk meningkatkan kualitas dan memperbaiki kedudukan perempuan diperlukan pendidikan khusus kaum perempuan yang diajarkan oleh kaum perempuan sendiri. Dalam hal ini perlu adanya upaya untuk meningkatkan kemampuan kaum perempuan, baik di bidang intelektual, kepribadian ataupun keterampilan.

Harapan dan cita-cita rahma dalam memperjuangkan pendidikan Rahmah beliau wujudkan dengan mendirikan sekolah yang bernama Diniyah Putri pada tahun 1923. Melalui lembaga pendidikan ini Rahmah el-Yunusiyah, memperluas misi kaum modernis untuk menyediakan sarana pendidikan bagi kaum perempuan yang akan menyiapkan mereka menjadi warga yang produktif dan muslim yang baik. Ia menciptakan wacana baru di Minangkabau dan meletakkan tradisi baru 
dalam pendidikan bagi kaum perempuan di kepulauan Indonesia. Dan Diniyah Putri merupakan sekolah pertama akademi agama untuk wanita yang berdiri di Indonesia. ${ }^{5}$

Anak-anak perempuan dan perempuan dewasa mungkin saja mendapat dorongan untuk mengaji Al-Qur'an dan shalat akan tetapi tidak sama dengan lakilaki, mereka memiliki sedikit peluang untuk dapat melek aksara Melayu yang menjadi bahasa nasional Indonesia, atau Belanda, sebagai bahasa pendidikan modern. Rahmah el-Yunusiyah percaya bahwa kaum wanita membutuhkan model pendidikan tersendiri yang terpisah dari laki-laki, karena ajaran Islam memberikan perhatian khusus kepada watak dan peran kaum perempuan dan mereka membutuhkan lingkungan pendidikan tersendiri di mana topik-topik ini bisa dibicarakan secara bebas. ${ }^{6}$

Rahmah merasa bahwa pendidikan bersama (campuran) membatasi kemampuan kaum perempuan untuk menerima pendidikan yang cocok dengan kebutuhan mereka. Rahmah ingin menawarkan kepada anak-anak perempuan pendidikan sekuler dan agama yang setara dengan pendidikan yang tersedia bagi kaum laki-laki, lengkap dengan program pelatihan dalam hal keterampilan yang berguna sehingga kaum perempuan dapat menjadi anggota masyarakat yang produktif. Hal inidapat disimak dari perkataannya sebagai berikut:

"Diniyah School putri akan selalu mengikhtiarkan penerangan agama dan meluaskan kemajuannya kepada perempuan-perempuan yang selama ini susah mendapatkan penerangan agama Islam dengan secukupnya dari kaum lelaki lantaran perempuan segan bertanya kepadanya. Inilah yang menyebabkan terjauhnya perempuan Islam dari penerangan agama sehingga menjadikan kaum perempuan itu rendam karam ke dalam kejahilan. ...Saya harus memulai, dan meyakini bahwa pasti akan banyak pengorbanan yang akan dituntut dari diri saya, Jika kakanda bisa, kenapakah saya adiknya, tidak bisa. Jika laki-laki bisa menempuh pendidikan yang lebih tinggi, kenapa perempuan tidak bisa."7

\footnotetext{
${ }^{5}$ http://syafieh.blogspot.com pemikiran pendidikan rahmah el-yunusia. html, Diakses 24 November 2019

${ }^{6} \mathrm{http} / / /$ syafieh.blogspot.com pemikiran pendidikan rahmah el-yunusia. html, Diakses 24 November 2019

${ }^{7}$ http://syafieh.blogspot.com pemikiran pendidikan rahmah el-yunusia. html, Diakses 24 November 2019
} 
Tujuan pendidikan perempuan menurut Rahmah adalah meningkatkan kedudukan kaum perempuan dalam masyarakat melalui pendidikan modern yang berlandaskan prinsip-prinsip Islam. Ia percaya bahwa perbaikan posisi kaum perempuan dalam masyarakat tidak dapat diserahkan kepada pihak lain, hal ini harus dilakukan oleh kaum perempuan sendiri. Melalui lembaga seperti itu, ia berharap bahwa perempuan bisa maju, sehingga pandangan lama yang mensubordinasikan peran perempuan lambat laun akan hilang dan akhirnya kaum perempuan pun akan menemukan kepribadiannya secara utuh dan mandiri dalam mengemban tugasnya sejalan dengan petunjuk agama.

Perempuan dalam Islam memiliki keistimewaan lain, yaitu salah satunya adalah hak menuntut ilmu. Dan ini merupakan sisi lain dari keagungan perempuan dalam Islam. Hak menuntut ilmu bagi perempuan dalam Islam tidak dibedabedakan apakah dia seorang perempuan merdeka atau budak. Dalam satu riwayat dari Abū Burdah disebutkan bahwa Rasulullah Saw bersabda, siapa saja yang mempunyai seorang budak perempuan kemudian ia mengajarkan ilmu dan adab dengan baik. Selanjutnya Kemudian, dia memerdekakan dan menikahinya maka dia mendapat dua pahala." 8

Menurut Islam, ilmu memang menjadi hak mendasar yang tidak boleh dihilangkan. Karena satu masyarakat tidak akan maju karena makanan, minuman, pakaian, dan tempat tinggal saja. Karena ini semua adalah hak materi harus memiliki hak maknawi dan spiritual yakni ilmu pengetahuan. Dan hidup tidak mungkin berjalan dengan baik tanpa ini. Itulah sebabnya hati, ruh, dan nalar harus selalu diremajakan dengan ilmu.

Tercatat dalam sejarah Islam, pendidikan khusus bagi wanita telah dilaksanakan atau dipraktikkan oleh Rasulullah Saw. Dimana beliau meluangkan satu haris khusus untuk mengajari kaum wanita. Disamping itu, secara khusus Rasulullah Saw mendidik ibu-ibu kaum Mukminin-istri beliau (ummahāt alMu'minīn). ${ }^{9}$

8 https://www.hidayatullah.com/artikel/tsaqafah/read/2015/02/28/39653/hak-hak-wanitadalam-islam.html, Diakses 24 November 2019

${ }^{9}$ Syekh Muhammad al-Ghazālī, Dr. Muhammad Sayyid Țanțāwī, dan Dr. Ahmad 'Umar Hāsyim, al-Mar'ah fì al-Islām (Kairo: Maṭba'ah Akhbār al-Yaum, 1991: 87 
Dalam karya ilmiah penulis akan mengungkapkan "Kesetaraan Hak dalam Pendidikan (Studi Sejarah Rahmah Elyunusiyah Memperjuangkan Hak-Hak Wanita)" dengan menggunakan studi kepustakaan dengan pendekatan sejarah. Dengan pokok bahasan penelitian ini adalah bagaimana Kesetaraan Hak dalam pendidikan (Studi Pada Sejarah Perjuangan Rahmah Elyunusiyah Dalam Memperjuangkan Hak-Hak Wanita Dalam Pendidikan).

\section{PEMBAHASAN}

\section{A. Urgensi pendidikan Islam}

Pendidikan adalah salah satu kata kunci untuk setiap manusia supaya ia mendapatkan ilmu. Hanya melalui pendidikan ilmu akan didapat dan terserap dengan baik.. Tak heran bila kini pemerintah mewajibkan program belajar 9 tahun agar masyarakat menjadi pandai dan beradab. Pendidikan juga merupakan metode pendekatan yang sesuai dengan fitrah manusia yang memiliki fase tahapan dalam pertumbuhan.

Didalam pendidikan Islam terdapat 3 (tiga) tahap uraian kegiatan, yakni: tilawah (membacakan ayat Allah), tazkiyah (mensucikan jiwa) dan ta'limul kitab wa sunnah (mengajarkan Al kitab dan Al hikmah). Pendidikan dapat merubah cara berpikir yang masyarakat jahiliyah menjadi umat terbaik disebabkan pendidikan memiliki atau mempunyai kelebihan. Pendidikan memiliki ciri atau tanda pembentukan pemahaman keislaman yang utuh dan menyeluruh, pemeliharaan apa yang telah dipelajari dan dipahaminya, pengembangan atas ilmu yang diperolehnya dan agar tetap pada jalur syariah. Hasil dari pendidikan Islam akan membentuk manusia berjiwa tenang, akal yang cerdas dan fisik yang kuat serta banyak beramal. ${ }^{10}$

Pendidikan Islam berpadu dalam pendidikan ruhiyah, (pemahaman) fikriyah (pemikiran) dan amaliyah (aktivitas). Nilai-nilai ajaran Islam ditanamkan dalam individu membutuhkan tahapan-tahapan selanjutnya dikembangkan dan di implementasikan kepada pemberdayaan di segala bidang kehidupan manusia. Potensi yang dikembangkan tersebut kemudian diarahkan kepada pengaktualan

${ }^{10}$ A. Yunus, Filsafat Pendidikan, (Bandung: CV. Citra Sarana Grafika, 1999), 56 
potensi atau kemampuan dengan memasuki berbagai bidang kehidupan. (QS. Ali Imran (3) : 103): berikut ini:

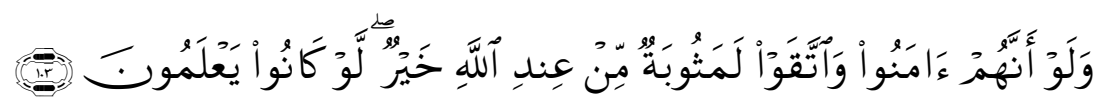

Terjemahnya:

Sesungguhnya kalau mereka beriman dan bertakwa, (niscaya mereka akan mendapat pahala), dan Sesungguhnya pahala dari sisi Allah adalah lebih baik, kalau mereka mengetahui. ${ }^{11}$

Pendidikan yang diajarkan Allah Swt melalui Nabi Muhammad Saw bersumber dari Al Qur'an sebagai rujukan atau pedoman dan pendekatan agar dengan pendidikan akan membentuk masyarakat yang sadar dan menjadikan Allah Swt sebagai Ilah saja. Kehidupan manusia akan selamat di dunia dan akhirat. Hasil dari ilmu yang didapat adalah kenikmatan yang sangat besar, yaitu dalam bantuk pengetahuan, harga diri, kekuatan dan persatuan. Tujuan utama dari pendidikan Islam ialah supaya manusia memiliki gambaran tentang keislaman yang jelas, utuh dan menyeluruh.

Interaksi dalam diri seseorang pasti memberi pengaruh kepada penampilan, sikap dan tingkah laku dan amalnya sehingga menghasilkan akhlaq atau perilaku yang baik. Akhlak atau perilaku ini perlu dilatih dengan latihan membaca dan mengkaji Al-qur'an, shalat malam, shaum (puasa) sunnah, berhubungan kepada setiap keluarga dan masyarakat umum. Semakin sering seseorang melakukan latihan maka semakin banyak amalnya dan semakin mudah dalam melakukan kebajikan. Selain itu latihan akan menghantarkan dirinya memiliki kebiasaan yang akhirnya menjadi gaya hidup sehari-hari.

\section{B. Dasar Pendidikan Islam}

Pengertian Dasar Pendidikan Islam (Konseptual) Dalam Kamus Umum Bahasa Indonesia kata dasar memiliki banyak arti diantaranya alas atau fondasi,

\footnotetext{
${ }^{11}$ Departemen Agama RI, Al-Qur'an dan Terjemahnya (Bandung, Mizan, 2009), 64
} 
pokok atau pangkal. ${ }^{12}$ Menurut Nata dasar pendidikan adalah segala sesuatu yang umumnya bersifat konsep, pemikiran dan ide yang mendasari, melandasi dan mengasasi pendidikan. ${ }^{13}$ Oleh sebab itu dasar pendidikan islam yaitu segala sesuatu yang bersifat konsep, pemikiran dan ide yang mendasari, melandasi dan mengasasi pendidikan Islam. Menurut Mujib dan Mudzakkir dasar pendidikan Islam yaitu landasan operasional yang dijadikan untuk merealisasikan dasar ideal/sumber pendidikan Islam. ${ }^{14}$

Namun pendapat ini disanggah oleh Nata, ia bependapat bahwa dasar pendidikan bukanlah landasan opersional akan tetapi lebih merupakan landasan konseptual. Karena dasar pendidikan tidak secara langsung memberikan dasar bagi pelaksanaan pendidikan, namun lebih memberikan dasar bagi penyusunan konsep pendidikan. ${ }^{15}$ dan menurut penulis sendiri bahwa apa yang disampaikan oleh Nata ini lebih tepat. Pengertian asas Pendidikan Islam dalam kamus umum bahasa Indonesia kata asas memiliki makna suatu kebenaran yang menjadi pokok dasar atau tumpuan berfikir atau berpendapat. ${ }^{16}$

Disebutkan pula bahwa terdapat kosa kata prinsip yang memiliki makna yang sama dengan kata asas, jadi dapat dikatakan bahwa kata asas memiliki makna yang sama dengan prinsip. Oleh karena itu yang dimaksud dengan asas pendidikan Islam ialah prinsip pendidikan Islam yaitu kebenaran yang dijadikan pokok dasar dalam merumuskan dan melaksanakan pendidikan Islam. prinsipprinsip ajaran islam ini digunakan dalam merumusksan dan melaksanakan ajaran islam. Prinsip-prinsip ini sifatnya permanen, karena merupakan ajaran, dan karenanya tidak boleh dihilangkan atau diubah, karena ketika prinsip tersebut dihilangkan atau diubah maka menghilangkan sifat dan karakter pendidikan islam tersebut. ${ }^{17}$

12 W.J.S. Purwadarminta, Kamus Umum Bahasa Indonesia (Jakarta: Balai Pustaka. 2001), 267.

${ }^{13}$ Abudin Nata, Ilmu Pendidikan Islam, (Jakarta: Kencana Prenada Media Group. 2012.), 90.

${ }^{14}$ Abdul Mujib dan Jusuf Mudzakkir, Ilmu Pendidikan Islam (Jakarta: Kencana Prenada Media, 2000), .44.

${ }^{15}$ Nata, Ilmu, 63.

${ }^{16}$ Purwadarminta, Kamus, 63.

${ }^{17}$ Nata, Ilmu, 102. 
Perbedaan asas dan dasar dalam pendidikan Islam bertolak dari awal kata asas dan dasar yang pada asal katanya yaitu mempunyai makna yang sama, dimana kata asas merupakan serapan dari bahasa arab yang maknanya adalah dasar. Asas adalah kebenaran yang menjadi pangkal dasar atau tumpuan berfikir dalam berpendapat sedangkan dasar yaitu segala sesuatu yang bersifat konsep, pemikiran dan ide yang mendasari, melandasi dan mengasasi. Letak Perbedaaan antara asas dasar pendidikan Islam dan dasar pendidikan Islam secara tegas dijelaskan oleh Nata, beliau menegaskan kata dasar digunakan sebagai tempat yang dijadikan sandaran atau pijakan dalam membangun sesuatu atau sebagai landasan yang digunakan untuk mengembangkan konsep atau teori. Adapun kata prinsip sama maknanya dengan asa yaitu kebenaran yang dijadikan hal yang paling utaman yang menjadi dasar dalam berfikir dan bertindak. Kata prinsip atau asas merupakan landasan operasional atau landasan bertindak.

Menurut Langgulung, bahwa dasar dalam pendidikan Islam terdapat enam model, yaitu historis, sosiologis, ekonomi, politik, administrasi, psikologi dan filosofis. Pendapat Langgulung ini, menurut Mujib dan Mudzakir dinilai agak sekuler, karena selain tidak memasukkan dasar agama, juga dapat menjadi filsafat sebagai induk dari segala dasar ilmu. Menurut Mujib dan Mudzakir, bahwa dalam Islam, dasar operasional segala sesuatu yaitu agama, sebab agama menjadi frame bagi setiap aktivitas yang bernuansa keislaman. Dengan dasar agama, maka seluruh kegiatan kependidikan menjadi bermakna, mewarnai dasar lain, dan bernilai ubudiyah. ${ }^{18}$

Oleh karena itu, dasar operasional pendidikan yang enam di atas perlu ditambahkan dasar yang ketujuh, yaitu agama. Oleh karena itu, sebab antara ilmu pengetahuan, agama dan filsafat memiliki landasan ontologis, epistemologis dan aksiologis yang pada intinya terdapat hal berbeda, maka dalam buku dasar-dasar pendidikan Islam tersebut perlu dibedakan. Secara ontologis dan epistemologis, ilmu pengetahuan merupakan rasionalisasi dan sistematisasi terhadap berbagai fenomena yang dilihat, diamati, dan dicacat manusia.

18 https://makalahnih.blogspot.com/2014/09/makalah-pendidikan-islam.html, Diakses 24 November 2019 
Jika yang dilihat, diamati, dan dicatat itu fenomena sosial, maka ia menjadi rumpun ilmu-ilmu social. Jika yang dilihat, diamati, dicatat fenomena alam fisik, maka ia menjadi rumpun ilmu-ilmu alam (natural sciences atau sains). Selanjutnya, filsafat adalah induk dari segala ilmu berupa konsep-konsep tentang hakikat atau inti segala sesuatu yang dihasilkan melalui berpikir secara spekulatif, sistematis, mendalam, radikal dan universal. Adapun agama dilihat dari segi sumbernya berasal dari Tuhan. Namun dilihat adari yang dipahami dan dipraktikkan oleh manusia, termasuk ilmu agama, yaitu ilmu yang dihasilkan melalui ijtihad manusia yang berdasarkan pada agama. Selanjutnya secara aksiologis, baik ilmu pengetahuan, filsafat maupun agama tergantung kepada yang menggunakannya. Jika ketiga hal tersebut digunakan untuk kebaikan, maka akan menjadi baik, dan jika digunakan untuk keburukan, maka akan menjadi buruk.

Berdasarkan pada analisis tersebut, dasar pendidikan Islam, dibagi menjadi tiga bagian, yaitu dasar religious, dasar filsafat, dan dasar ilmu pengetahuan. Uraian tentang ketiga macam dasar ini, dapat dikemukakan sebagai berikut. 1 . Dasar Religius Dasar religius sebagaimana dikemukakan Abdul Mujib dan Jusuf Mudzakir adalah dasar yang diturunkan dari ajaran agama. Adapun tujuan dari agama yaitu untuk memelihara jiwa manusia (hifdz an-nafs), memelihara agama (hifdz al-din), memelihara akal pikiran (hifdz al-'aql), memelihara keturunan (hifdz an-nasl), memelihara harta benda (hifdz al-maal). Pendapat ini mengatakan, bahwa inti ajaran agama ialah terbentuknya akhlak mulia yang bertumpu pada hubungan yang harmonis antara manusia dengan Tuhan, dan antara manusia dengan manusia.

Di dalam al-Qur'an, manusia diperkenalkan dengan sifat-sifat dan kekuasaan Allah 1 dengan tujuan agar manusia menyadari bahwa dirinya sangat berutang budi pada-Nya, dan sekaligus agar manusia meniru sifat-sifat Allah. Selain di dalam Al-qur'an terdapat kisah para nabi dan tokoh-tokoh umat Islam masa lalu, maksudnya agar diikuti sifatnya yang baik yang mereka contohkan, dan dijauhi sifatnya yang buruk. Demikian pula di dalam Al-qur'an, terdapat perintah mengerjakan ibadah seperti shalat, puasa, zakat, dan haji. Semua perintah ibadah ini agar terbentuk akhlak yang mulia. Selanjutnya di dalam al-Qur'an terdapat 
pula berbagai larangan Tuhan dengan tujuan agar memelihara akhlak manusia. Dengan demikian, dasar religius berkaitan dengan memelihara dan menjunjung hak-hak asasi manusia, serta memelihara moralitas manusia.

Dasar religius ialah dasar yang bersifat humanisme-teoricentris, yaitu dasar yang memperlakukan dan memuliakan manusia sesuai dengan petunjuk Allah 1 dan dapt pula berarti dasar yang mengarahkan manusia agar berbakti, patuh, dan tunduk kepada Allah 1, dalam rangka memuliakan manusia. Dasar religius seperti inilah yang harus dijadikan dasar bagi perumusan berbagai komponen pendidikan. Visi, misi, tujuan, kurikulum, bahan ajar, sifatm dan karakter pendidikan, peserta didik, hubungan pendidik dengan peserta didik, lingkungan pendidikan, manajemen pengelolaan, dan lainnya harus berdasarkan pada dasar religius. ${ }^{19}$

\section{Sejarah Pendidikan Wanita (Pendidikan Wanita Dalam Islam )}

\section{Pendidikan Wanita Pada Zaman Dahulu}

Para wanita Arab sebelum datangnya Islam telah mempunyai hak dan kesempatan belajar yang terkenal pada masa itu, maka di kalangan wanita telah terdapat wanita-wanita tukang tenung dan penyai'r-penya'ir dan orang-orang yang mempunyai pengetahuan dalam menulis. Di dalam buku-buku yang berbahasa Arab disebutkan banyak sekali nama-nama wanita yang terkenal pada masa jahiliyah dan masa permulaan Islam.

Pendidikan wanita dalam Islam tidak terlepas pada sejarah awal penyebaran Islam di masa Nabi Muhammad SAW, Islam mengajarkan persamaan status pria dengan wanita dalam aspek-aspek spritual dan kewajiban keagamaan dan yang membedakan adalahnya akhlak yang baik dan buruk. Sebagaimana di contohkan pada masa Nabi masih hidup seorang wanita bangsawan dan berketurunan tinggi dari kalangan Quraisy penah mencuri dan karenanya ia dikenakan hukuman. Dan ada seseorang yang ingin membelanya. Kemudian Nabi mengambil sikap dan berkata, apakah kamu akan membela seseorang dalam hukum yang telah ditentukan Tuhan?. Selanjutnya beliau berpidato yang isinya

${ }^{19}$ https://makalahnih.blogspot.com/2014/09/makalah-pendidikan-islam.html, Diakses 24 November 2019. 
menyebutkan. "Wahai manusia sesungguhnya orang-orang sebelum kamu menjadi sesat, karena apabila seorang bangsawan mencuri, mereka membiarkannya, dan apabila orang-orang lemah mencuri mereka menegakan hukum terhadapnya, demi Allah sekiranya Fathimah anak Muhammad mencuri, Muhammad akan memotong tangannya". ${ }^{20}$

Kalau kita teliti tentang kandungan matan hadits diatas, sangat jelas kedudukan wanita dan pria sama kedudukannya dalam hukum. Demikian pula dalam keagamaan, mereka akan mendapat pahala yang sama. Allah menegaskan posisi wanita dalam Al Quran sebagai berikut :

"Dan para wanita mendapat hak yang seimbang dengan kewajibannya menurut cara yang makruk. Akan tetapi para suami mempunyai satu tingkatan dari pada isterinya"

a) Pendidikan Wanita Pada masa Nabi SAW

Pada zaman Nabi SAW, wanita mulai mendapatkan kedudukan yang terhormat dan sederajat dengan kaum pria, karena sebelumnya pada zaman jahiliyah, kaum wanita mendapatkan kedudukan yang sangat rendah dan hina, hingga kelahiran seorang anak perempuan dalam keluarga dianggap suatu yang aib dan harus membunuh anak itu semasa bayi.

Pada masa ini, Nabi meyamakan kedudukan wanita dan pria dalam hal menuntut ilmu sebagai manifestasi ayat ini diriwayatkan pula dari Nabi s.a.w bahwa beliau menganjurkan agar istrinya diajarkan menulis, dan untuk ini beliau berkata kepada Asy-Syifa' (seorang penulis di masa jahiliyah) tidak maukah Anda mengajar mantera kepada Hafsah sebagaimana engkau telah mengajarkannya menulis. $^{21}$

b) Pendidikan Wanita Pada masa Sahabat

Pada masa ini telah banyak bermunculan ahli ilmu agama dan pengetahuan, seperti Sitti Hafsah isteri Nabi pandai menulis, dan 'Aisyah binti Sa'ad juga pandai menulis. Siiti Aisyah isteri Nabi pandai membaca Al-quran dan

\footnotetext{
${ }^{20} \mathrm{http} / / /$ walidrahmanto.blogspot.com/2011/06/pendidikan-wanita-dalam-islam.html, Diakses 24 November 2019.

${ }^{21}$ Fahmi, Asma Hasan, Sejarah dan Filsafat Pendidikan Islam (Jakarta: Bulan Bintang, 1979), 45.
} 
tak pandai dalam menulis tetapi beliau adalah seorang ahli fiqh yang terkenal sebagaimana diakui oleh Urwah bin Zubair seorang ahli fiqh yang terkenal dalam hal ini beliau mengatakan bahwa: yang sangat tepopuler dalam hal ini beliau mengatakan bahwa: belum pernah saya melihat seorang yang lebih alim dalam ilmu Fiqh, ilmu kedokteran dan ilmu sya'ir selain diantara para wanita selain dari seorang Aisyah. Kemudian ada pula seorang wanita yang bernama Ummu Salamah dapat membaca dan tidak pandai menulis, dan Al-Khansa' seorang penyair yang loyal, nasionalis dan pejuang. Hindun binti 'tabah, Laila binti Salma dan Sitti Sakinah binti Al-Husain, seorang ahli yang pandai dalam bidang syair. Demikian pula Aisyah binti Talhah adalah seorang wanita yang ahli dalam kritik syair. $^{22}$

Pada masa kemelut politik pertentangan antara Khalihah Ali dengan Mu'awwiyah, ada beberapa wanita yang terkenal ikut dalam kancah politik, seperti Hindun binti 'Idi bin Qais, 'Akrasyah binti al-Athrusy dll yang mereka itu membantu 'Ali melawan Mu'awiyah. Setelah itu pula Mu'awiyah sangat tertarik menggunakan wanita dalam kancah politik kerajaan, salah satunya yaitu AlKhaizuran dan Syajaratud-Durr.

c) Pendidikan Wanita Pada masa Dinasti Abasiyah

Pada masa ini, agama Islam telah tersebar luas kebeberapa tempat, demikian pula kebudayaan serta kemajuan dimasa Bani Abbas di bagian Timur dan Barat, telah memunculkan para tokoh wanita yang ikut serta dalam kegiatan intelektual dan kesenian, pengatahuan agama, sastera dan kesenian. Para budak wanita mempunyai kesempatan yang besar untuk mempersiapkan diri dalam bidang satera dan kesenian sehingga harga budak wanita menjadi lebih tinggi sesuai dengan kecakapan yang dimilkinya. Wanita-wanita yang terkenal dalam bidang pengetahuan dan syi'ir antara lain, 'Aliyah binti al-Mahdi, Fadhlun, 'Aisyah binti Ahmad bin Qadim al-Qurthubiyah, Lubna, Walladah binti alKhalifah al-Mustakfi Billah, Qamar. ${ }^{23}$

${ }^{22}$ Ibid.,

${ }^{23} \mathrm{http}$ ://walidrahmanto.blogspot.com/2011/06/pendidikan-wanita-dalam-islam.html, Diakses 24 November 2019. 
Sebagian perempuan adapula yang ahli dibidang ilmu agama dan hadits dan para sarjana wanita Muslimah yang terkenal jujur dalam ilmu dan amanah dalam riwayatnya. Seorang ahli dan pakar dibidang hadis yang terbesar bernama Al-Hafiz Az-zahabi dalam menyaring rijalul hadis yang telah mengeluarkan hadis sebanyak 4000 orang perawi hadis dan dalam hal ini beliau menyampaikan, 'saya tak melihat dari kalangan perempuan orang yang terkena tuduhan dan tidak pula orang-orang yang mencoreng nama mereka (sebagai perawi hadits yang sangat terpercaya). perempuan yang terkenal dalam perawi hadits adalah Karimah Almarwaziyah dan Sayyidah Al-Wuzara. Ibnu Abi Ushaibi'ah menyebutkan didalam bukunya Thabaqatul Athibba' tentang dua perempuan yang bekerja sebagai dokter dan mereka mengobati perempuan istna Khalifah Al-Mansur di Andalus. Diantara mereka andalan Zainab, seorang dokter mata yang sangat terkenal dari Bani Uwad.

Apabila kita bandingkan kondisi pendidikan dan peranan wanita Islam abad pertangahan dengan wanita yang ada di Eropa Kristen maka akan sangat terlihat perbedaan yang mencolok, di Griek (Eropa) kecuali Sparta dan Plato, saat itu wanita tidak diberikan persamaan hak dalam pendidikan dan sosial sebagai mana yang diperoleh oleh laki-laki, mereka menganggap wanita sebagai benda yang dapat menjamin kepuasan dan kesenangan mereka meskipun mereka mencapai peradaban yang tinggi dan kemajuan dalam bidang ilmu pengetahuan.

\section{Beberapa Pendapat Tentang Pendidikan Wanita}

Adalah kewajiban bagi wanita untuk memperoleh pendidikan ilmu agama seperti shalat, puasa, zakat, haji, sebagaimana kewajiban untuk berdagang dan bertransaksi. Jika seorang suami tidak dapat untuk memberikan padanya ilmu tersebut, maka wanita, menurut Islam wajib untuk mencarinya. Shaikh Usman dan Fodio, seorang guru yang sangat terkenal dari Nigeria mengatakan dalam Irshad Al-Ikhwan,'Jika seorang suami tidak mengizinkannya, maka istri diperbolehkan keluar mencari ilmu tanpa seizinnya, dan tidak ada kesalahan, dan tidak ada kesalahan baginya dan pula tidak dosa baginya karena itu. Peraturan ini seharusnya mendorong para suami agar mendukung istrinya dalam mencari ilmu, 
sewajib bagi suami untuk menafkahi keluarganya, sesungguhnya ilmu adalah utama (dan wajib dipelihara dan diamalkan)". ${ }^{24}$

Namun dalam praktek atau implementasi persamaan spiritual tidak selalu disertakan dengan persamaan dalam bidang intelektual di antara wanita dan pria. Hal ini dapat terlihat kadang-kadang dalam bidang pendidikan. Studi tentang pendidikan bagi wanita dalam umat Islam memperlihatkan dua pendapat yang berbeda yaitu yang menerima dan bahkan yang menolak.

a) Pendapat yang menolak pendidikan wanita

Para ulama yang menolak pendidikan wanita, yaitu tidak boleh mengajar wanita selain agama dan Al Quran, dan dilarang mengajarkan menulis. Wanita yang diberi pelajaran menulis diserupakan dengan ular yang menghirup racun. Pendukung pendapat ini mengambil dasar dari Ali bin Abi Thalib yang menjumpai seorang pria yang sedang mengajarkan menulis kepada seorang wanita, lalu beliau menegur, "jangan kamu menambah kejahatan dengan kejahatan." Selanjutnya pendukung pendapat ini meriwayatkan bahwa 'Umar bin Khattab melarang wanita belajar menulis. Disamping itu mereka menisbahkan para wanita dengan kekurangan dari segi akal dan agama, dan kekurangan ini merupakan faktor yang menyebabkan tidak boleh mengajarkan pengetahuan kepada para wanita. ${ }^{25}$

b) Pendapat yang memperbolehkan pendidikan wanita

Para pendukung yang memberi pengajaran kepada wanita dengan menggunakan dalil-dalil dari hadits Nabi yang menganjurkan untuk memberi pengajaran kepada wanita, sebagian dari hadits tersebut ialah, "menuntut ilmu diperlukan atas setiap muslim dan muslimah". "setiap orang yang memilki walidah (hamba) dan mengajarkannya serta mendidiknya, kemudian ia memerdekakannya dan mengawininya, maka ia akan mendapat dua buah pahala." 26

\footnotetext{
${ }^{24}$ Soekarno dan Ahmad Supardi, Sejarah Dan Filsafat Pendidikan Islam (Bandung: Angkasa 1983), 64

${ }^{25}$ Ibid, 65 .

${ }^{26}$ Ibid.,
} 
Islam memberikan persamaan hak dan kewajiban dalam menuntut ilmu bagi waita sebagaimana laki-laki, namun yang menjadi perhatian khusus adalah tentang penekan pendidikan akhlaq. Sebagai contoh Ibnu Urdun berpendapat bahwa anak-anak perempuan harus mempelajari shalat dan agama serta menambahkan pelajaran-pelajaran yang lain, akan tetapi ia tidak sepakat mengajarkan syi'ir dan menulis kepada anak perempuan, serta ia tidak menyetujui memberikan pendidikan anak perempuan bersama-sama dengan anak laki-laki dalam sebuah tempat, meskipun ada pendapat yang membolehkan belajar bersama-sama antara anak perempuan dan anak laki-laki.

\section{Hasil dan Pembahasan}

Pada abad XX, kondisi sosial Sumatra Barat sedang berubah. Penduduk Minangkabau berkembang menjadi masyarakat yang secara intensif mengalami alur proses modernisasi. Dalam kerangka pembaharuan Islam masyarakat Minang tidak saja menyaksikan berdirinya lembaga-lembaga pendidikan modern menggantikan lembaga pendidikan tradisional sistem surau, namun juga tampilnya sejumlah ulama yang mengetengahkan pemikiran baru yang disemangati oleh perubahan dan modernisasi. Keluarga yang memiliki latar belakang yang taat beragama dan aktif dalam gerakan pembaharuan menjadi ladang bagi bersemainya kesadaran pembaharuan dalam diri Rahmah Elyunusia. Beliau menilai bahwa kaum perempuan sebagai tiang negara mestinya mendapatkan pendidikan yang lebih baik sebagai kaum lelaki. pendidikan kaum perempuan yang terbelakang ini, menurutnya berakar dari persoalan pendidikan dan melalui bidang ini dapat terselesaikan. ${ }^{27}$

Seiring dengan pembaruan Islam yang dibawa oleh para ulama penuntut ilmu di Timur Tengah pada awal abad ke XX, sejumlah sekolah dengan latar belakang agama berdiri di berbagai daerah Minangkabu menggantikan sistem pendidikan tradisional yang berbasis surau. Pada 10 Oktober 1915, Zainuddin Labay El Yunusy mendirikan sekolah agama Islam yang dinamakan Diniyah School dan memasukkan pelajaran umum dalam kurikulum dan dilaksanakan

\footnotetext{
${ }^{27}$ Rohmatun Lukluk Isnaini, Ulama Perempuan Dan Dedikasinya Dalam Pendidikan Islam (Telaah Pemikiran Rahmah El-Yunusiyah), Jurnal Pendidikan Agama Islam Volume 4 Nomor 1 Mei 2016 ISSN (p) 2089-1946 \& ISSN(e) 2527-4511, 237 -3.
} 
dengan cara pendidikan modern, menggunakan alat peraga dan memiliki perpustakaan. Sekolah ini menerima murid perempuan di kelas yang sama dengan murid laki-laki dan hal tersebut merupakan hal yang baru. Rahmah ikut mendaftar, dan diterima duduk di bangku kelas tiga (setara Tsanawiyah) oleh pihak sekolah menyesuaikan dengan kemampuannya. ${ }^{28}$

Selain hadir dikelas pada pagi hari di Diniyah School, Rahmah memimpin kelompok belajar di luar kelas pada sore hari. Dan ia melihat, dicampurnya peserta didik lelaki dan perempuan dalam kelas yang sama, perempuan tidak bebas dalam mengutarakan pendapat, ide, dan menggunakan haknya dalam belajar. Rahmah melihat banyak problem perempuan terutama dalam perspektif fikih tidak dijelaskan secara mendetail oleh guru yang notabene laki-laki, sementara peserta didik perempuan malu untuk bertanya. Bersama dua sahabatnya Sitti Nansiah dan Djawana Basyir, Rahmah mempelajari fikih lebih mendalam kepada Abdul Karim Amrullah di Surau Jembatan Besi. Mereka tercatat sebagai murid-murid perempuan pertama yang ikut belajar di Surau Jembatan Besi, sebagaimana dicatat oleh Hamka. ${ }^{29}$

Pada Saat beliau sekolah di Diniyah School, Ria turut bergabung dengan Persatuan Murid-murid Diniyah School (PMDS) salah satu organisasi yang ada pada zaman tersebut. Ketika duduk di kelas enam, Rahmah merundingkan idenya untuk mendirikan sekolah perempuan sendiri kepada para sahabat perempuannya di PMDS. Ia menginginkan agar perempuan memperoleh pendidikan yang sesuai dengan fitrah mereka dan dapat diamalkan dalam kehidupan sehari-hari. Kesungguhannya dalam mewujudkan dan melaksanakan ide tersebut beliau sampaikan kepada kakaknya, ia berkata kepada kakanya bahwa: Kalau saya tidak mengawalinya dari sekarang, maka kaum saya akan tetap selalu terbelakang. Saya harus mulai, dan saya yakin akan banyak pengorbanan yang dituntut dari diri saya. Jika kakanda bisa, kenapakah saya, adiknya, tidak bisa. Jika lelaki bisa, kenapa perempuan tidak bisa. ${ }^{30}$

\footnotetext{
${ }^{28}$ https://id.wikipedia.org/wiki/Rahmah_El_Yunusiyah, Diakses 24 November 2019

${ }^{29}$ https://id.wikipedia.org/wiki/Rahmah_El_Yunusiyah, Diakses 24 November 2019

${ }^{30} \mathrm{https}$ ://id.wikipedia.org/wiki/Rahmah_El_Yunusiyah, Diakses 24 November 2019
} 
Rahmah selanjutnya meluaskan penguasaannya dalam beberapa ilmu terapan supaya ia dapat mengajarkannya pada murid-muridnya. Melalui keahlian dan kemampuan yang dimiliki oleh mak tuonya, ia belajar ilmu kebidanan. Ia sempat mengikuti kursus kebidanan di beberapa rumah sakit kepada beberapa orang dokter, Ia belajar kepada Sofyan Rasad salah satu dokter yang ada di rumah sakit Kayutaman dan mendapatkan izin menjalani praktik. Secara privat, ia mempelajari dan menadalami olahraga dan senam dengan seorang guru yang berasal dari Belanda yang kebetulan mengajar di Guguk Malintang. Pergaulan Rahmah sebagai pimpinan sekolah mempertemukannya dengan guru-guru yang mengajar di Padang panjang. Ia berkenalan dengan Djusair, Rosminanturi Gaban, dan Sitti Akma yang membawanya untuk mendalami ilmu tentang memasak, pelajaran-pelajaran tentang kewanitaan, menjahit, dan berenang. Selanjutnya, ia belajar bertenun tradisional memakai alat tenun yang bukan mesin dan pada masa itu banyak dilakukan oleh masyarakat Minangkabau. ia mendapatkan Pengalamannya bertenun dari pusat pertenunan rakyat seperti Pandai Sikek dan Silungkang. Berbagai ilmu lainnya seperti ilmu hayat dan ilmu alam ia pelajari sendiri dari buku. Penguasaannya dalam berbagai ilmu ini suatu waktu memengaruhi metode pendidikan yang ia terapkan dan laksanakan di Diniyah Putri. ${ }^{31}$ Rahmah selalu memohon petunjuk kepada Allah Swt tentang harapanya tersebut, sebagaimana tertuang dalam doanya yang ditulis di buku catatannya:

Ya Allah Ya Rabbi, bila ada dalam ilmu-Mu apa yang menjadi cita-citaku ini untuk mencerdaskan anak bangsaku terutama anak-anak perempuan yang masih jauh tercecer dalam bidang pendidikan dan pengetahuan, ada baiknya Engkau ridhai, maka mudahkanlah Ya Allah jalan menuju cita-citaku itu. Ya Allah, berikanlah yang terbaik untuk hamba-Mu yang lemah ini. Amin. ${ }^{32}$

Cita-citanya dalam bidang pendidikan perempuan adalah agar semua perempuan Indonesia memperoleh kesempatan penuh menuntut ilmu pengetahuan yang sesuai dengan fitrah wanita sehingga dapat diamalkan dalam kehidupan sehari-hari dan mendidik mereka sanggup berdiri sendiri di atas kekuatan kaki

\footnotetext{
${ }^{31}$ https://id.wikipedia.org/wiki/Rahmah_El_Yunusiyah, Diakses 24 November 2019.

${ }^{32} \mathrm{http}: / /$ syafieh.blogspot.com/2013/02/pemikiran-pendidikan-rahmah-el-yunusia.html, Diakses 24 November 2019.
} 
sendiri, yaitu menjadi ibu pendidik yang cakap dan aktif serta bertanggung jawab kepada kesejahteraan bangsa dan tanah air, dimana kehidupan agama mendapat tempat yang layak Rahmah merumuskan cita-cita pendidikanya menjadi tujuan Perguruan Diniyah Putri yang didirikannya, yaitu: "Melaksanakan pendidikan dan pengajaran berdasarkan ajaran Islam dengan tujuan membentuk putri yang berjiwa Islam dan Ibu guru yang cakap, aktif, serta bertanggung jawab mengenai kesejahteraan masyarakat dan tanah air dalam pengabdian kepada Allah Swt."

Melihat tekad keras dari Rahmah, kakaknya Zainuddin Labay mendukung apa yang di cita-citakan oleh Rahmah.. Dalam menjalankan cita-citanya Rahmah sangat meyakini Al-Qur'an surat Muhammad ayat 7 yang artinya: "Hai orangorang yang beriman, jika kamu menolong Allah, maka Allah akan menolong kamu”. Begitu yakinnya ia akan janji Allah ini sehingga selalu dijadikannya pegangan dalam berbuat kebajikan. Rahmah juga mendasarkan argumennya kepada hadis yang menyatakan bahwa menuntut ilmu adalah kewajiban bagi semua muslim, laki-laki maupun perempuan. Bunyi hadis ini, kata Rahmah, sering dikutip di hadapan saya oleh laki-laki maupun perempuan Minang sebagai bukti bahwa kaum perempuan muslim diperintahkan oleh Tuhan untuk menuntut ilmu, dan cara terbaik untuk melaksanakan ini adalah dengan masuk sekolah.

Cita-cita dan gagasan Rahmah el-Yunusiyah tentang pentingnya pendidikan bagi kaum perempuan mungkin dipengaruhi oleh pengalamannya dalam menjalani pendidikannya sendiri. Meskipun Rahmah hanya sempat mengecap pendidikan dasar di Padang Panjang, studinya yang mendalam terhadap agama adalah sesuatu yang tidak lazim bagi seorang perempuan pada awal abad kedua puluh di Minangkabau. Ia memperoleh pendidikan melalui pengaturan khusus dengan beberapa ulama modernis yang terkemuka, dalam pola kaum muda di zamannya. Selain itu, Rahmah belajar kerumahtanggaan dengan seorang bibi maternal, dan mempelajari soal kesehatan dan pemberian pertolongan pertama di bawah bimbingan enam orang dokter kelahiran India. Ia belajar senam dengan seorang guru Belanda di Sekolah Menengah Putri di Padang Panjang. Pada dasarnya Rahmah memperoleh pendidikan atas inisiatifnya sendiri, pada saat pendidikan formal bagi kaum perempuan hanya tersedia bagi segelintir orang. 
Gagasan Rahmah untuk mendirikan pendidikan bagi kaum perempuan sempat dirundingkannya dengan teman-temannya di Persatuan Murid-murid Diniyah School (PMDS) yang ia pimpin, merekapun menyetujui dan mendukung gagasan itu. Maka pada tanggal 1 November 1923, sekolah itu di buka dengan nama Madrasah Diniyah lil al-Banat, dipimpin oleh Rangkayo Rahmah elYunusiyah, yang oleh murid-muridnya dari angkatan tiga puluhan akrab dipanggil " Kak Amah”. Peserta didik angkatan yang pertama terdiri dari kaum ibu-ibu muda berjumlah 71 orang, dengan menggunakan Mesjid Pasar Usang sebagai tempat untuk belajar. Pada waktu itu proses pembelajaran berlangsung dengan sistem halaqah dan hanya mempelajari ilmu-ilmu agama dan gramatika bahasa arab.

Dalam mendirikan gedung perguruan ini Rahmah sangat mandiri. Ketika Rahmah mendirikan gedung perguruannya pada tahun 1927 dan mengalami kekurangan biaya penyelesaian gedung tersebut, ia menolak bantuan yang diulurkan kepadanya dengan halus dan bijaksana. Ia ingin memperlihatkan kepada kaum laki-laki bahwa wanita yang selama ini dipandang lemah dan rendah derajatnya dapat berbuat sebagaimana laki-laki, bahkan bisa melebihinya. Maka secara diplomatis Rahmah mengatakan:

"Usul ini sangat dihargai oleh pengurus dan guru-guru, akan tetapi buat kaum perempuan (puteri) akan mencoba melayarkan sendiri pencalangnya sampai ke tanah tepi dan mana kala tenaga putri tidak sanggup lagi menyelamatkan pencalang itu, maka dengan sepenuh hati pengharapan guru-guru dan pengurus akan memohonkan kembali usul-usul engku-engku sekarang, kepada engku-engku yang menurut kami patut kami menyerahkan pengharapan kami itu". ${ }^{33}$

Tampaknya pikiran Rahmah setengah abad yang lalu sejalan dengan pendapat kaum wanita pada hari ini yaitu: "membangun masyarakat tanpa mengikutsertakan golongan wanita adalah sebagai seekor burung yang ingin terbang dengan satu sayap saja. Mendidik seorang wanita berarti mendidik seluruh manusia. ".Kunci mendidik Rahmah terletak pada 3M, yaitu Mendidik dengan

${ }^{33}$ http://syafieh.blogspot.com/2013/02/pemikiran-pendidikan-rahmah-el-yunusia.html, Diakses 24 November 2019 
keteladanan, Mendidik bukan hanya mengajar dan Mendidik tanpa emansipasi, yang akan dijelaskan pada poin-poin berikut:

\section{Mendidik Dengan Keteladanan}

Sebelum dan sesudah menjadi seorang guru, Rahmah telah banyak memberikan keteladanan, tidak hanya pada muridnya akan tetapi pada masyarakat sekitar. Ia banyak memberikan keteladanan melalui kepribadian dan perjuangannya melawan penjajah kolonial Belanda Salah satunya kedisiplinan. Ia selalu memberi contoh pada murid-muridnya, bagaimana disiplin itu harus dijalankan dan dipatuhi, seperti jadwal kegiatan sejak bangun tidur pukul 05.00 pagi sampai tidur kembali pukul 10.30 malam.

Kemudian saat Rahmah harus ditahan oleh Belanda karena menentang kebijakan Belanda yang melarang memasukkan kurikulum Islam ke dalam sekolah dan harus menerapkan pendidikan secara sipil. ${ }^{34}$ Kepribadiannya yang sabar dan pantang menyerah juga ia buktikan saat sekolah yang baru tiga tahun didirikannya runtuh oleh gempa tahun 1926, beliau tidak putus asa dan bangkit kembali mencari dana bantuan bersama pamannya hingga ke selat Malaka. ${ }^{35}$

Menurut Natsir yang pernah dekat dengan Rahmah, Rahmah tidak memiliki sifat buruk sangka kepada orang lain.Dalam dirinya tidak terdapat sifat ananiyah yakni sifat egois yang selalu mementingkan diri sendiri. ${ }^{36}$ Selain itu, ia mempunyai kepribadian yang sederhana, lemah lembut dan tawadhu. ${ }^{37}$

\section{Mendidik Bukan Hanya Mengajar}

Menurut Rahmah, Guru bukan hanya sebagai pengajar, namun ia juga merupakan seorang pendidik. Fauziah Fauzan, cicit Rahmah yang kini menjadi pimpinan Diniyyah Puteri School pernah menyampaikan, guru adalah pengajar dan pendidik, oleh karenanya, guru hendaklah sanggup dalam melaksanakan

\footnotetext{
${ }^{34}$ Hamka, Ayahkuu (Jakarta: Penerbit Djajamurni, 1967), 265.

${ }^{35}$ Hariti Sastriyani. Glossarium Seks dan Gender (Yogyakarta: Caravasti Books, 2009), 58.

${ }^{36}$ Devi Wahyuni, “Kebijakan Kepemimpinan Perempuan Dalam Pendidikan Islam (Refleksi Atas Kepemimpinan Rky Rahmah El Yunusiyah Sebagai Syaikhah Pertama di Indonesia)", 17 dalam Jurnal Sawwa terbitan IAIN Walisongo Semarang No. 2, Vol. 3, tahun 2009.

${ }^{37}$ Aminuddin Rasyad. Disertasi Perguruan Diniyyah Puteri Padangpanjang: 1923-1978, Suatu Studi Mengenai Perkembangan Sistem Pendidikan Agama. (Jakarta: IAIN Syarif Hidayatullah Jakarta, 1982), 176.
} 
kedua fungsi yang dimaksud, dengan seimbang dan optimal dalam menyiapkan generasi. $^{38}$

Sebagai pendidik atau guru, Rahmah ingin menunjukkan bahwa dalam mendidik tidak hanya mengajarkan teori, namun lebih dari itu. Seorang pendidik, harus sanggup dalam mendidik peserta didiknya agar menjadi orang beriman dan bertakwa.

\section{Mendidik Tanpa Emansipasi}

Rahma walaupun ia menolak pembatasan mencari ilmu bagi perempuan, namun Rahmah menyetujui emansipasi seperti yang digaungkan oleh feminis. Rahmah ingin perempuan tetap pada fitrahnya dan anak didiknya menjadi ibu yang baik untuk anak-anaknya kelak, karenanya ia tetap memasukkan pendidikan rumah tangga seperti menjahit, memasak dan keterampilan rumah tangga lainnya ke dalam kurikulum sekolahnya.

Ini terlihat saat materi kurikulum sekolahnya sarat dengan berbagai mata pelajaran (sehingga jumlah pelajaran dalam satu minggu mencapai 45 jam), mengingat pentingnya pelajaran ketrampilan dan kerumahtanggaan, maka pelajaran tersebut oleh Rahmah diberikan pada sore harinya. ${ }^{39}$.

Karena menurut Rahmah, masyarakat bisa baik bila rumah tangga dari masyarakat tersebut juga baik, karena rumah tangga adalah tiang masyarakat dan masyarakat adalah tiang negara, sebagaimana yang diajarkan oleh agama Islam. Ia mempunyai tekat yang kuat bahwa setiap wanita menjadi ibu yang baik dalam rumah tangganya, masyarakat dan sekolah. Menurut Rahmah hal ini hanya dapat dicapai melalui pendidikan.

\section{Konsep Pendidikan Adab Rahmah}

Berdasarkan tujuan pendirian Diniyyah Puteri yang ingin membentuk putri berjiwa Islam dan ibu pendidik yang cakap dan aktif serta bertanggung jawab tentang kesejahteraan masyarakat dan tanah air, atas dasar pengabdian

\footnotetext{
${ }^{38}$ Tamar Djaja. Rohana Kudus Srikandi Indonesia: Riwayat Hidup dan Perjuangannya. (Jakarta: Penerbit Mutiara, 1980), 11.

${ }^{39}$ Deliar Noer. Gerakan Moderen Islam di Indonesia 1900-1942, (Jakarta: Pustaka LP3ES. 1982), 62-63.
} 
kepada Allah SWT. ${ }^{40}$ Maka Rahmah juga memasukkan pelajaran Adab dalam kurikulum sekolahnya, hal ini terlihat pada tahun 1928, dimana kelas satu hingga kelas enam Ibtidaiyah (Sekolah Dasar) mendapatkan pelajaran Adab. ${ }^{41}$

Pelajaran Adab merupakan pelajaran yang sangat penting untuk diajarkan, Imam Abu Hamid Al-Ghazali menafsirkan adab sebagai pendidikan diri jasmani dan rohani (ta'dib al-zahir wa'l batin), yang meliputi empat perkara: perkataan, perbuatan, akidah dan niat seseorang. ${ }^{42}$ Maka proses untuk melahirkan insan mulia ini dikatakan ta'dib atau pendidikan dalam Islam.

Menurut sarjana-sarjana terdahulu, kandungan ta'dib adalah akhlak. Hal ini kemudian dibenarkankan oleh hadis Nabi Saw yang menyatakan bahwa misinya adalah untuk menyempurnakan akhlak manusia. ${ }^{43}$ Ta'dib merupakan istilah yang paling tepat untuk menggambarkan proses pendidikan yang sebenarnya, karena ia memasukkan empat ciri penting pendidikan:

1. Proses penyempurnaan insan secara berperingkat (al-tarbiyah)

2. Pengajaran dan belajar mengajar (al-ta'lim wa'l ta'allum), yakni bertumpu pada aspek kognitif, kecerdasan dan akidah seorang peserta didik.

3. Disiplin diri (riyadah al-nafs) yang meliputi jasad, ruh dan akal

4. Proses penyucian dan pemurnian akhlak (tahdhib al-akhlaq). ${ }^{44}$

Mengingat begitu pentingnya pelajaran adab, pada tahun 1933, kelas satu hingga kelas tiga tsanawiyah yang setara dengan sekolah mengenah pertama juga mendapat pelajaran sama pada saat kurikulum studi gender masih diterapkan di beberapa perguruan tinggi, salah satunya perguruan tinggi islam negeri, Rahmah dengan sekolah yang didirikannya mempu mengintegrasikan, menyatukan dan menerapkan pendidikan umum, pendidikan agama dan pendidikan keperempuanan dalam satu kurikulum dan sistem pesantren. maka dapat disimpulkan, Diniyyah Puteri lah pelopor integrasi tiga pendidikan tersebut.

\footnotetext{
${ }^{40}$ Ibid.,

${ }^{41}$ Ajat Burhanuddin dan Oman Fathurrahman. Tentang Perempuan Islam: Wacana dan Gerakan. (Jakarta: Gramedia Pustaka Utama. 2004). 18-19.

${ }^{42}$ Rasyad. Disertasi Perguruan, 50.

${ }^{43}$ Adian Husaini. Pendidikan Islam: Membentuk Manusia Berkarakter dan Beradab. (Jakarta: Cakrawala Publishing. 2012). hlm.'122.

${ }^{44}$ Rasyad. Disertasi Perguruan, 50.
} 
Sebagai seorang Guru, Rahmah mendidik para muridnya dengan akhlak yang bisa dijadikan teladan, seperti kesabaran, kejujuran, kedisiplinan, ketekunan, kesederhanaan dan sikap optimis, keteladanan akhlak inilah yang hilang dari banyak Guru saat ini. Kemudian Rahmah telah mampu mendidik tanpa emansipasi, tanpa menuntut kesetaraan gender bagi perempuan dalam segala lini kehidupan. Ia merasa perlu mendidik tanpa emansipasi karena menyadari pentingnya peran perempuan sebagai madrasah pertama untuk anak-anaknya kelak.

Rahmah el-Yunusiyah tidak mendapatkan pendidikan formal yang memadai. Ia hanya dapat menempuh sekolah dasar selama 3 tahun. Kompotensi yang dimiliki Rahmah dalam baca-tulis Arab dan Latin ia peroleh dari kedua kakaknya, Zaenuddin Labay dan Muhammad Rasyid. Akan tetapi, perannya sebagai tokoh pembaharu pendidikan Islam bagi perempuan di Minangkabau terbukti mampu meningkatkan kualitas dan memperbaiki kedudukan perempuan islam di masanya, didasarkan pada kemampuannya menciptakan pendidikan modern menurut coraknya sendiri, yang dikondisikan dengan kebutuhan kaum perempuan saat itu. Kecerdasan Rahmah mendorong ia bersikap kritis, tidak lekas puas, dan selalu mencari hal-hal yang baru dalam hidupnya.

Rahmah mempunyai harapan membangun sekolah khusus kaum perempuan. Hal ini dilatar belakangi dari kesadaran rahmah bahwa ketimpangan sosial dan ketidakadilan yang dialami kaumnya. Ia memandang bahwa kaumnya jauh tertinggal dari laki-laki, mereka berada dalam kebodohan, ketertinggalan dan kepasrahan pada keadaan untuk itulah pentingnya pendidikan bagi wanita. Baginya perempuan memiliki peran yang sangat penting dalam kehidupan. Perempuan adalah pendidik/guru anak yang akan mengendalikan jalur kehidupan mereka selanjutnya. Dalam sebuah catatan hariannya, Rahmah pernah menuliskan: Ya Allah Ya Rabbi, bila ada dalam ilmu-Mu apa yang menjadi keinginanku ini untuk mencerdaskan anak bangsaku khususnya perempuan yang masih jauh tercecer dalam bidang pendidikan dan pengetahuan, ada baiknya 
Engkau ridhai, maka mudahkanlah Ya Allah jalan menggapai cita-citaku itu. Ya Allah, berikanlah yang terbaik untuk hambamu yang lemah ini. ${ }^{45}$

Visi Rahmah tentang peran perempuan adalah peran dengan beberapa segi: sebagai pendidik, pekerja sosial demi kesejahteraan masyarakat, teladan moral, muslimah yang baik dan juru bicara untuk mendakwahkan pesan-pesan Islam. Rahmah ingin agar wanita indonesia memiliki kesempatan penuh untuk menuntut ilmu yang sesuai dengan kodrat wanita hingga bisa diamalkan dalam kehidupan sehari-hari. Kenyataan inilah yang terus mendorong semangatnya untuk terus belajar sehingga dapat mendidik kaumnya menurut dasar agama dan mendirikan Diniyah School khusus putri. ${ }^{46}$

Di Dalam dunia pendidikan Islam, Rahmah merupakan pelopor bagi pendidikan muslimah di Indonesia maupun dunia. Pada usianya yang relatif muda, 23 tahun, Rahmah el-Yunusiyah telah mendirikan lembaga pendidikan khusus bagi kaum perempuan, yaitu Diniyah School Putri (1923 M.) guna memberikan pendidikan bagi kaum perempuan Minang pada masa itu. Rahmah ingin menunjukan bahwa wanita yang selama ini dipandang lemah dan rendah derajatnya dapat berbuat sebagaimana laki-laki, bahkan bisa melebihinya. Tampaknya pikiran Rahmah el-Yunusiyah setengah abad yang lalu sejalan dengan pendapat kaum wanita dewasa ini yaitu: "membangun masyarakat tanpa mengikutsertakan kaum wanita adalah sebagai seekor burung yang ingin terbang dengan satu sayap saja. Mendidik seorang wanita berarti mendidik seluruh manusia.

Diniyah Putri merupakan akademi agama yang pertama bagi putri yang berdiri Indonesia. Pendirinya Rahmah El-Yunusiyah, memperluas misi kaum modernis untuk menyediakan sarana pendidikan Islam modern yang mengintegrasikan pengajaran ilmu-ilmu agama dan umum secara klasikal, lengkap dengan program pelatihan dalam hal keterampilan yang bermanfaat unutk kaum perempuan sehingga sanggup menyiapkan mereka menjadi warga yang

\footnotetext{
${ }^{45}$ https://www.kompasiana.com/aliyazahra/5520ccf18133114e7419fb6e/rahmaelyunusiyah-kartini-pendidikan-islam, Diakses 24 November 2019

${ }^{46} \mathrm{https}$ ://www.kompasiana.com/aliyazahra/5520ccf18133114e7419fb6e/rahmaelyunusiyah-kartini-pendidikan-islam, Diakses 24 November 2019
} 
produktif dan muslimah yang baik. Ia membuat wacana baru di Minangkabau, dan meletakkan tradisi baru dalam pendidikan bagi kaum perempuan di kepulauan Indonesia.

Kontribusi Rahmah Dalam dunia pendidikan, tidak hanya dengan mendirikan Diniyyah Puteri School saja, tetapi ia juga mendirikan beberapa sekolah lainnya, diantaranya;

1. Menyesal School, yaitu sekolah pemberantasan buta huruf di kalangan ibu-ibu rumah tangga. Sekolah ini didirikan pada tahun 1925 dan berlangsung selama tujuh tahun yaitu sampai tahun 1932. Kemudian sekolah ini tidak dilanjutkan.

2. Yunior Institut Putri, sebuah sekolah umum setingkat dengan Sekolah Rakyat pada masa penjajahan Belanda atau Vervolgschool, didirikan pada tahun 1938.

3. Sekolah Dasar dengan pengantar utama khusus menggunakan bahasa Belanda yang bernama Islamitisch Hollandse School (IHS) yang setara dengan HIS (Hollandsch Inlandse School) yakni sekolah dasar dengan pengantar bahasa Belanda.

4. Sekolah Dasar Masyarakat Indonesia (DAMAI)

5. Sekolah khusus guru agama Putra yang berdiri tahun 1940 yang bernama Kulliyatul Mu'allimin El-Islamiyah (KMI). Tujuan didirikannya untuk memenuhi kebutuhan masyarakat terhadap guru-guru agama putra yang banyak didirikan oleh masyarakat di Sumatera Barat. Keempat sekolah ini berhenti beraktivitas semenjak zaman penjajahan Jepang.

6. Pada tahun 1947 ia kembali mendirikan empat buah lembaga pendidikan agama putri dalam bentuk lain, yaitu Diniyah Rendah Putri (SDR), sekolah setingkat Sekolah Dasar dengan lama pendidikannya tujuh tahun,

7. Sekolah Diniyah Menengah Pertama Putri Bagian A Tiga Tahun (DMP Bagian A), Sekolah Diniyah Menengah Pertama Bagian B Lima Tahun (DMP Bagian B), dan Sekolah Diniyah Menengah Pertama Bagian C Dua Tahun (DMP Bagian C). Tiga buah sekolah yang disebut terakhir setingkat dengan Sekolah Menengah Pertama ( SMP) dengan bidang studi agama dan bahasa Arab menjadi mata pelajaran pokok.

8. Akademi Diniyah Putri yang lama pendidikannya tiga tahun pada tahun 1964. Pada tanggal 22 November 1967 Akademi ini dijadikan Fakultas dirasat islamiyah dan merupakan fakultas dari Perguruan Tinggi Diniyah Putri. Fakultas ini diakui dan dinyatakan setara dengan Fakultas Ushuluddin Institut Agama Islam Negeri (IAIN) untuk tingkat Sarjana Muda. $^{47}$

\footnotetext{
${ }^{47}$ https://www.kompasiana.com/aliyazahra/5520ccf18133114e7419fb6e/rahmaelyunusiyah-kartini-pendidikan-islam, Diakses 24 November 2019
} 
Di samping sebagai pendidik, Rahmah juga seorang pejuang. Dalam Ensiklopedia Islam terbitan PT Ichtiar Baru Van Hoeve (IBVH) disebutkan bahwa Rahmah merupakan orang pertama yang mengibarkan bendera merah putih di sekolahnya setelah mendengar berita proklamasi kemerdekaan Indonesia.

Pada tahun 1933, Rahmah mengetuai rapat umum kaum Ibu di Padang Panjang yang bertujuan meningkatkan martabat perempuan, ia melibatkan diri sebagai anggota pengurus "Serikat Kaum Ibu Sumatra" (SKIS) yang berjuang melalui penerbitan majalah bulanan perempuan. Rahmah pun pernah mengetuai Kutub Khannah atau taman bacaan masyarakat Padang Panjang tahun 1935. Pada tahun yang sama, ia bersama Ratna Sari mewakili kaum ibu Sumatera Tengah di Jakarta mewakili dalam rangka kongres perempuan Di kongres ini ia memperjuangkan ide tentang busana perempuan Indonesia hendaknya memakai selendang (kerudung). Rahmah adalah salah satu pelopor jilbab lilit pertama di Indonesia yang sesuai dengan kaidah syar'i dalam Islam. Gagasan tersebut menggambarkan pandangan hidupnya yang agamis, usahanya memasukan nilainilai Islam yang kaffah ke dalam kebudayaan Indonesia. ${ }^{48}$

Pada masa Jepang Rahmah memasuki organisasi "Anggota Daerah Ibu” (ADI) yang didirikan oleh kaum ibu Sumatera Tengah yang bertujuan untuk hamper sama dengan apa yang dicita-citakannya. Bersama kaum ibu Rahmah termasuk orang yang menentang Jepang dimana Jepang menggunakan perempuan Indonesia sebagai noni-noni penghibur tentara Jepang di rumah-rumah kuning, khususnya Sumatera Tengah. Dan ia menuntut Jepang agar menutup rumah maksiat tersebut, karena tidak sesuai dengan agama dan budaya masyarakat setempat.

Selain aktif, dalam berbagai organisasi Rahmah juga aktif dalam berbagai aktivitas social dan politik dalam mengupayakan perjuangan kemerdekaan Indonesia. Rahmah ialah orang yang memandang betapa pentingnya kerja sama dengan Jepang untuk memperjuangkan kemerdekaan. Oleh Karena itu, pada masa penjajahan Jepang dia memasuki beberapa lembaga yaitu lembaga militer, politik,

\footnotetext{
${ }^{48} \mathrm{https}$ //www.kompasiana.com/aliyazahra/5520ccf18133114e7419fb6e/rahmaelyunusiyah-kartini-pendidikan-islam, Diakses 24 November 2019
} 
maupun sosial yang didirikan pemerintah Jepang, yang digunakan sebagai wadah memperjuangkan Kemerdekaan Indonesia, antara lain:

1. Gyu Gun Ko En Kai (lascar rakyat)

2. Menjadi ketua Haha no Kai (organisasi perempuan) di Padang Panjang, untuk membantu pemuda-pemuda indonesia yang terhimpun dalam Gyu Gun (lascar rakyat) agar mereka kelak dapat dimanfaatkan dalam perang revolusi perjuangan bangsa.

3. Pada saat perang asia-pasifik, sekolah Diniyah Putri gedungnya dua kali digunakan sebagai rumah sakit darurat untuk menampung korban kecelakaan kereta api. Atas peristiwa ini Diniyah School Putri mendapat Piagam Penghargaan dari Pemerintah Jepang. ${ }^{49}$

Setelah masa diera kemerdekaan, Rahmah terus melebur bergabung dalam dalam organisasi soaial dan politik untuk membangun negeri Indonesia tercinta. Kiprah Rahmah dalam upaya ini antara lain:

1. Mempelopori pembentukan Tentara Keamanan Rakyat (TKR)

2. Melindungi serta mengayomi barisan-barisan para pejuang yang dibentuk organisasi Islam waktu itu, seperti Laskar Sabilillah dan Laskar Hizbulwatan

3. Ditunjuk sebagai anggota Sub-panitia Keamanan bagian Tawanan Politik dan Tawanan Perang, dengan SK ketua Delegasi RI dalam Local Joint Committee Sumatera Tengah di Bukittinggi.

4. Memimpin dapur umum untuk TNI dan Barisan Pejuang.

5. Ia diundang untuk menghadiri "Kongres Pendidikan Antar Indonesia" di Yogyakarta sebagai wakil Sumatera.

6. Sekitar tahun 1952-1954 dia menjadi anggota Dewan Partai Masyumi di Jakarta, kemudian menjadi penasihat Masyumi Muslimat di Sumatera Tengah hingga 1955.

7. Terpilih menjadi anggota DPR RI dari Partai Masyumi untuk Daerah pemilihan Sumatera Tengah hingga tahun 1958..$^{50}$

Rahmah adalah seorang arsitek pendidikan progresif di Indonesia, telah merombak konstruksi pemikiran perempuan dan laki-laki yang bias gender dalam pembangunan bangsa. Mengarahkan pendidikan perempuan Islam yang produktif

\footnotetext{
${ }^{49}$ https://www.kompasiana.com/aliyazahra/5520ccf18133114e7419fb6e/rahmaelyunusiyah-kartini-pendidikan-islam, Diakses 24 November 2019

${ }^{50} \mathrm{https}$ ://www.kompasiana.com/aliyazahra/5520ccf18133114e7419fb6e/rahmaelyunusiyah-kartini-pendidikan-islam, Diakses 24 November 2019
} 
dan kondusif sehingga dapat menjadi cikal bakal kebangkitan perempuan di Indonesia.

\section{PENUTUP}

Bagi kebanyakan masyarakat Indonesia sikap apriori terhadap perempuan yang bersekolah masih merupakan domain utama kehidupan sehari-hari. Lihat saja, bagaimana istilah dapur, sumur, kasur begitu populer dikalangan masyarakat. Ungkapan ini ingin menegaskan bahwa sehebat dan secerdas apapun seorang perempuan, pada akhirnya "kodrat" dan "takdir" perempuan akan kembali pada kehidupan rumah tangga yang hanya mengurusi urusan memasak, mencuci dan seks. Ungkapan dan anggapan tersebut telah lama berlangsung sejak ratusan tahun dan bukan merupakan hal yamng baru. Dalam kelompok masyarakat matrilinialpun, seperti Sumatera Barat tempat kelahiran dan perjuangan Rahmah, asumsi bahwa perempuan tidak layak belajar masih kerap diperbincangkan.

Rahmah merupakan satu dari sebagian perempuan yang menolak stereotype tersebut. menurutya, perempuan memiliki hak belajar dan mengajar yang sama dengan laki-laki. Bahkan, jika dibandingkan dengan laki-laki, perempuan juga dapat memiliki kecerdasan yang tak kalah hebat. Persoalan terletak pada akses pendidikan. Saat itu, jauh sebelum Indonesia merdeka, sistem pendidikan di Nusantara masih sangat jauh dari yang diharapkan dan perempuan belum memiliki akses pendidikan yang sama dengan laki-laki.

Baginya, seorang perempuan walaupun hanya berperan sebagai ibu rumah tangga, tetap harus memiliki tanggung jawab sosial atas kesejahteraan masyarakat, agama, dan tanah airnya. Tanggung jawab tersebut dapat diberikan melalui pendidikan, baik di lingkungan keluarga maupun di sekolah. Mungkin, seandainya Rahmah masih hidup ia akan sepakat dengan gagasan masa kini yang menyebutkan bahwa membangun masyarakat tanpa melibatkan perempuan bagaikan seekor burung yang terbang dengan satu sayap. Mendidik seorang perempuan berarti mendidik semua manusia. Karena, sebagaimana diyakini oleh semua orang, bahwa pendidikan mampu memberikan sumbangan yang besar 
dalam usaha memodernisasi suatu masyarakat. Dan nampaknya Rahmah telah bekerja untuk itu.

\section{DAFTAR PUSTAKA}

Ajat Burhanuddin dan Oman Fathurrahman. Tentang Perempuan Islam: Wacana dan Gerakan. Jakarta: Gramedia Pustaka Utama. 2004

Departemen Agama RI. Al-Qur'an dan Terjemahnya. Bandung, Mizan, 2009

Djaja, Tamar. Rohana Kudus Srikandi Indonesia: Riwayat Hidup dan Perjuangannya. Jakarta: Penerbit Mutiara, 1980

Fahmi, Asma Hasan. Sejarah dan Filsafat Pendidikan Islam. Jakarta: Bulan Bintang, 1979.

Hamka. Ayahkuu. Jakarta: Penerbit Djajamurni. 1967.

http://syafieh.blogspot.com/2013/02/pemikiran-pendidikan-rahmah-elyunusia.html, Diakses 24 November 2019.

http://walidrahmanto.blogspot.com/2011/06/pendidikan-wanita-dalam-islam.html, Diakses 24 November 2019.

https://id.wikipedia.org/wiki/Rahmah_El_Yunusiyah, Diakses 24 November 2019

https://makalahnih.blogspot.com/2014/09/makalah-pendidikan-islam.html, Diakses 24 November 2019

https://www.hidayatullah.com/artikel/tsaqafah/read/2015/02/28/39653/hak-hakwanita-dalam-islam.html, Diakses 24 November 2019

https://www.kompasiana.com/aliyazahra/5520ccf18133114e7419fb6e/rahmaelyunusiah-kartini-pendidikan-islam, Diakses 24 November 2019

Husaini, Adian. Pendidikan Islam: Membentuk Manusia Berkarakter dan Beradab. Jakarta: Cakrawala Publishing. 2012

Isnaini, Rohmatun Lukluk. Ulama Perempuan Dan Dedikasinya Dalam Pendidikan Islam (Telaah Pemikiran Rahmah El-Yunusiyah), Jurnal Pendidikan Agama Islam Volume 4 Nomor 1 Mei 2016 ISSN (p) 20891946 \& ISSN(e) 2527-4511 251 -3

Mujib, Abdul dan Jusuf Mudzakkir, Ilmu Pendidikan Islam. Jakarta: Kencana Prenada Media, 2000 
Nata, Abudin. Ilmu Pendidikan Islam. Jakarta: Kencana Prenada Media Group. 2012.

Noer, Deliar. Gerakan Moderen Islam di Indonesia 1900-1942. Jakarta: Pustaka LP3ES. 1982

Purwadarminta, W.J.S. Kamus Umum Bahasa Indonesia. Jakarta: Balai Pustaka. 2001.

Rasyad. Aminuddin. Disertasi Perguruan Diniyyah Puteri Padangpanjang: 19231978, Suatu Studi Mengenai Perkembangan Sistem Pendidikan Agama. Jakarta: IAIN Syarif Hidayatullah Jakarta, 1982

Sastriyani, Hariti. Glossarium Seks dan Gender. Yogyakarta: Caravasti Books, 2009.

Soekarno dan Ahmad Supardi. Sejarah Dan Filsafat Pendidikan Islam. Bandung: Angkasa 1983.

Syekh Muhammad al-Ghazālī, Dr. Muhammad Sayyid Țanțāwī, dan Dr. Ahmad 'Umar Hāsyim, al-Mar'ah fì al-Islām. Kairo: Maṭba'ah Akhbār al-Yaum, 1991

Wahyuni, Devi. “Kebijakan Kepemimpinan Perempuan Dalam Pendidikan Islam (Refleksi Atas Kepemimpinan Rky Rahmah El Yunusiyah Sebagai Syaikhah Pertama di Indonesia)", 17 dalam Jurnal Sawwa terbitan IAIN Walisongo Semarang No. 2, Vol. 3, tahun 2009.

Yunus, A. Filsafat Pendidikan. Bandung: CV. Citra Sarana Grafika, 1999 